\title{
Attitudes towards housing equity release strategies among older home owners: A European comparison
}

\author{
Joris Hoekstra $^{1} \mathbb{D} \cdot$ Kees Dol $^{1}$
}

Received: 26 February 2020 / Accepted: 5 February 2021 / Published online: 21 February 2021

(C) The Author(s) 2021

\begin{abstract}
The ageing of European societies, the mounting pressure on pension systems, the rise of home ownership and the growth in house prices have sparked interest in housing equity release options and strategies. Much of the available literature approaches this topic through a financial lens, focusing on equity release schemes as a way to free up housing equity while remaining in the dwelling. However, there are also other ways in which housing wealth can be extracted, such as downsizing, moving to a rental dwelling or subletting part of the dwelling. There is very little recent international comparative insight into the perceptions and preferences of older home owners with regard to this matter. Which housing equity release strategy do they prefer and why? And to what extent is their decision to release housing equity influenced by the bequest motive? Based on focus group research in six European countries (Germany, the United Kingdom, Ireland, Hungary, Italy and the Netherlands), this paper observes some general trends and identifies a number of country specific variations.
\end{abstract}

Keywords Home ownership · Housing equity release strategies $\cdot$ Bequest motive · Comparative research

\section{Introduction}

Much of the wealth that individual households possess is stored in the owner-occupied house. Especially older home owners, who usually have completely or largely paid off their mortgage, tend to have a substantial amount of equity accumulated in the dwelling. It may be attractive or even necessary for them to release part of this housing equity in order to supplement the retirement income. Related to this, the idea of asset-based welfare has gained currency in the housing domain.

Joris Hoekstra

j.s.c.m.hoekstra@tudelft.nl

Kees Dol

cornoliodol@gmail.com

1 Faculty of Architecture and the Built Environment, Delft University of Technology, Julianalaan 134, 2628 BL Delft, Netherlands 
The general idea of asset-based welfare is that people can organize their own welfare arrangements when they have sufficient assets available. Asset-based policies should provide needy households with the means and opportunities to accumulate assets, thereby giving them greater control over their livelihoods (Elsinga and Hoekstra 2015). Sherraden (2003) argues that asset-based policies have a more profound impact on individuals than income-related subject subsidies. Asset-based policies are thought to empower people to act strategically and proactively, rather than being passive recipients of welfare benefits. The so-called egalitarian liberal tradition and the basic income/capital approach are strongly connected to ideas of asset-based welfare (Prabhakar 2018).

Despite its egalitarian roots, during the 1990's, the idea of asset-based welfare was embraced by those that supported the neo-liberal trends towards deregulation, privatization and marketization. After 2000, the concept also received much attention in the realm of housing. Policy-makers and academics increasing became aware of the fact that (older) home owners can employ the assets accumulated in their dwelling as a private safety net. They can use these assets as a supplement to (or even a substitute for) mandatory or voluntary pension schemes. Consequently, governments may perceive the existence of a large amount of housing assets as a justification to cut back spending on old-age benefits. In that way, housing asset-based welfare can function as a lever for welfare state restructuring (Hoekstra 2010) and as a potential solution for the looming pension crisis (see Toussaint and Elsinga 2009; Doling and Ronald 2010; Doling and Elsinga 2013). The general increase in home ownership rates in countries that were previously regarded as 'rental systems' also contributed to this development (Ronald 2008).

The emergence of housing asset-based welfare has certainly not been without debate or discussion. Various scholars (e.g. Elsinga and Hoekstra 2015) have argued that housing asset-based welfare policies can lead to increased social stratification and inequality, for example, between home owners and tenants. Moreover, at a certain point in time, housing assets are transferred across generations, which implies that (housing) asset-based welfare policies may also enhance intergenerational inequalities.

Housing equity release strategies For older homeowners, home ownership offers two main financial advantages. First of all, outright home ownership provides a 'free' roof over one's head. Second, the potential release of the equity that is stored in the dwelling can provide retirees with a significant monetary supplement. The most straightforward way for older home owners to release housing equity is to sell up and move, either to rental dwelling or to a smaller home ownership dwelling (downsizing). For households that want to extract housing equity without having to move, selling the dwelling and leasing it back, as well as subletting part of the dwelling, are possible options. In a sale-and-leaseback construction, the household sells the dwelling to a third party and receives a large part of the market value (typically $80 \%$ ). After the sale, the household pays a commercial rent and can continue to live in the same dwelling. A fifth option is the use of a so-called equity release scheme (ERS); a financial product that allows older home owners to release housing equity while remaining in the dwelling. It is remarkable that in the literature on housing equity release, it is particularly this option that has attracted a great amount of attention, often at the expense of the other four options.

The most common types of ERS are reverse mortgages (so-called loan model) and home reversion schemes (so-called sale model). A reverse mortgage allows older home owners to take out an (extra) mortgage loan on their dwelling. The money that is 
generated by this loan is paid out in a lump sum or in monthly payments. The mortgage loan does not require loan repayments or interest payments. Rather, the interest that is due is added to the total amount of the loan, which implies that the loan increases over time. In principle, the mortgage loan is only repaid when the dwelling is sold, for example, after the home owner passes away or moves to residential care. Reverse mortgages, sometimes also called life-time mortgages, are common in the United Kingdom but have also become available in a number of other European countries such as Italy, the Netherlands and Ireland (Al-Umaray 2018).

A second form of ERS is the home reversion scheme. In such a scheme, the home owner sells all or part of the property to a financial institution who will pay a lump sum in return. Such a lump sum tends to be considerably lower than the market value of the share of the dwelling that is sold. In exchange for this, the home owner has the right to remain in the dwelling for a fixed period of time and sometimes even for the rest of his/ her life. When the property is sold, the financial institution will receive the market value of the dwelling, equivalent to the part of the dwelling that it owns. Home reversion schemes are less popular than reversed mortgages, but they nevertheless exist in several European countries such as the United Kingdom, Ireland and Germany (Al-Umaray 2018).

The two types of ERS discussed above have their specific pros and cons (see also Reifner et al. 2009). For example, reversed mortgages can lead to very high debts, and potentially even cause negative equity, particularly if the home owner lives unexpectedly long. Home reversion schemes, on the other hand, are attractive in the case of a long life because there are no rent or interest payments due.

Even though the demand for in situ housing equity release solutions seems to be growing, particularly in times of increasing house prices, the actual take-up of ERS has remained fairly limited so far. This appears to be related to a widespread concern about the risks and complexities of ERS, as well as to a general distrust of providers of these products (Reifner et al. 2009; Jones et al. 2012). Indeed, the nature and extent of barriers to ERS is now a central part of research agendas on housing asset-based welfare (Jefferson et al. 2017).

Research questions and objective of the paper This paper provides international comparative evidence on the attitudes of older home owners towards the various housing equity release strategies and the bequest motive. It attempts to answer the following three research questions:

- What is the attitude of older home owners towards the different housing equity release strategies?

- What is the attitude of older home owners towards the bequest motive?

- To what extent, and why, do the answers to the two aforementioned research questions differ between the six selected European countries?

The paper adds to the existing body of literature by distinguishing between five different housing equity release strategies and by investigating the relative preferences for these five strategies. Little information on this topic is currently available. Most of the existing international comparative studies focus on housing equity release in general (e.g. Doling and Elsinga 2013), or on the use of ERS in particular (e.g. Haffner et al. 2015). A notable exception is the work of Chiuri and Japelli (2010), who examine 
decreases in home ownership rates (as a result of moves to the rental sector) among older population segments in various countries. However, this study is based on aggregate data rather than on individual attitudes and perceptions.

The empirical data that are analysed in this paper come from a research project on housing equity release and pensions that was carried out for the European Commission (AlUmaray et al. 2018). The authors of the present article coordinated the work stream on consumer perspectives that was part of this project. For this work stream, focus group discussions were held among older home owners in six European countries: the United Kingdom, Germany, the Netherlands, Ireland, Italy and Hungary. These countries were chosen because they represent different welfare regimes and, related to that, different institutional and cultural contexts.

The paper is organised as follows. We start with a brief description of the institutional and housing market contexts of the six selected countries (Sect. 2). Section 3 reviews the relevant literature on housing equity release strategies and the bequest motive, whereas Sect. 4 outlines the research methods. Section 5 presents the research results, and Sect. 6 contains the conclusions.

\section{Institutional and housing market contexts of the six selected countries}

The six countries in our analysis have different population sizes, welfare and pension systems and housing markets. International variations in attitudes towards housing equity release strategies need to be interpreted against these contextual differences. Therefore, Table 1 provides a brief overview of the main systemic features of the six countries under study (see Eckardt et al. 2018 for more extensive information on this issue).

Proportion of pensioners Table 1 shows that the proportion of persons above 65 significantly differs between the six selected countries. The 'greyest' countries are Italy and Germany, whereas Ireland is the 'greenest' country. The United Kingdom, the Netherlands and Hungary occupy a middle position. Not surprisingly, the old-age dependency ratios show a very similar pattern, with the highest ratios in Germany and Italy, and the lowest in Ireland.

Welfare state regimes The six countries under consideration belong to different welfare state regimes (see Fenger 2007; Hoekstra 2010; Doling and Elsinga 2013 for more details). Germany is a typical example of a corporatist welfare state regime, while the Dutch welfare state has both corporatist and social democratic features. The UK and Ireland represent the liberal model, whereas Italy and Hungary belong to, respectively, the Mediterranean and the Eastern European regime type. When interpreting the differences between countries, we will use the welfare state regime typology as a frame of reference. This allows us to make a sound comparison with other international comparative studies (e.g. Doling and Elsinga 2013; Delfani et al. 2014), which have followed a similar approach.

Pension systems After the Global Financial Crisis, the European pension systems have come under increasing budgetary pressure (Ebbinghaus 2015). Despite this general trend, differences between countries in terms of pension mix (mandatory versus voluntary) and pension generosity remain. With regard to the net replacement rates of the mandatory pension system, the Netherlands stands out with a rate of almost $100 \%$. Mandatory pension 


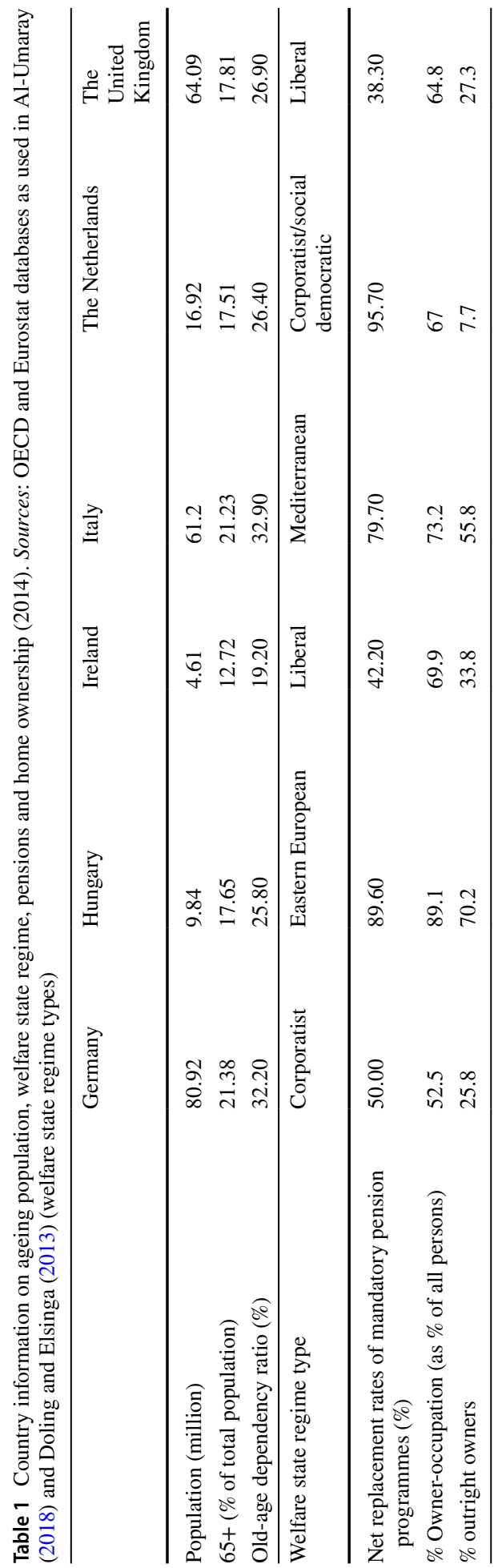


entitlements are also relatively generous in Hungary (89.60\% replacement rate) and Italy (79.70\% replacement rate). However, mandatory pension replacement rates are $50 \%$ or lower in Germany (50\%), Ireland (42.20\%) and the United Kingdom (38.30\%). In these countries, households largely have to rely on private savings or participation in voluntary pension funds if they want to have a pension that (largely) equals their pre-retirement income.

Home ownership and outright ownership The share of owner-occupation (expressed on the individual level rather than on the level of households) is very high in Hungary (around $90 \%$ ) and reasonably high in the United Kingdom, Italy, Ireland and the Netherlands (between 65 and 73\%). In Germany on the other hand, a country which is known for its extensive private rental sector (Haffner et al. 2009), the owner-occupation rate is only marginally above $50 \%$. In principle, a large owner-occupancy sector offers more possibilities for housing equity release than a small owner-occupancy sector. As far as this is concerned, the proportion of outright owners is also relevant since these owners generally have more equity accumulated in their dwelling than home owners with a mortgage.

As Table 1 shows, the proportion of outright ownership is particularly high in Hungary $(70.2 \%)$ and Italy (55.8\%) and remarkably low in the Netherlands (7.7\%). However, it should be noted that the low percentage for the Netherlands is connected to the particular fiscal system of this country, which allows households to deduct the paid mortgage interest from the taxable income. Nevertheless, for most Dutch older home owners, the outstanding mortgages only cover a limited part of the market value of the dwelling, which means that there still is considerable potential for the release of housing equity.

\section{Literature review: attitudes towards housing equity release strategies and bequest}

The central question of this paper is how older home owners that want to release housing equity choose between the different housing equity release strategies. The paper attempts to make a rather specific contribution to the existing body of research on releasing housing equity. Whereas much of this research has approached this topic from the perspective of the welfare state and/or the political economy (e.g. Malpass 2008; Doling and Ronald 2010; Elsinga and Hoekstra 2015; Lennartz and Ronald 2017), we take a more market and consumer oriented approach. In the literature review, we discuss relevant literature with a somewhat similar focus. Doing so, Sect. 3.1 takes an international comparative perspective, whereas Sect. 3.2 reviews some relevant single-country studies.

\subsection{International comparative perspective}

The DEMHOW project As far as we know, the European DEMHOW (Demographic Change and Housing Wealth) project was the first European comparative research project that approached housing equity release from a consumer oriented angle. This project resulted in both general and country (or welfare state regime) specific findings. A general conclusion was that many Europeans regard housing as a solid investment (Toussaint 2011; Doling and Elsinga 2013). Older European home owners tend to regard the owner-occupied dwelling as an asset that provides free housing services (income in kind) in old age. However, 
most older home owners are reluctant to tap into this asset by moving to a rental dwelling or by using an equity release scheme (Elsinga 2011; Toussaint 2011; Naumanen et al. 2012). They want to maintain and safeguard the housing asset as a precautionary nest egg that can be used when it is really needed, in situations of urgency. This means that housing equity release tends to be seen as an option of last resort.

In the DEMHOW project, older home owners often mentioned the wish to leave a bequest to their offspring as a major barrier that prevented them from releasing housing equity (Toussaint and Elsinga 2009; Toussaint 2011). By many, home ownership is seen as a cultural ideal. The 'old' family home may be surrounded with memories of raising children, and it is still the place where extended families gather in family meetings (Doling and Elsinga 2013). In order to keep this asset intact, older home owners may consider it their (cultural) duty to leave their dwelling as a bequest to their children or other relatives.

In addition to these general findings, the DEMHOW project also identified some interesting differences between European countries and welfare regimes. First of all, the perception of housing equity as a safeguard and precautionary fund was strongest in the Mediterranean (represented by Portugal in the qualitative DEMHOW research), corporatist (Germany and Belgium in DEMHOW) and Eastern European (Slovenia and Hungary in DEMHOW) welfare regime. In these types of countries, older home owners tend to see their housing as part of a family strategy. ${ }^{1}$ This may imply that adult children provide support to their parents with the expectation that the family home will be theirs in that way (Doling and Elsinga 2013, pp. 142-143). In such circumstances, interest in releasing housing equity is expected to be relatively limited.

In the liberal welfare state regime (the United Kingdom in DEMHOW), bequest motives seem to be somewhat less important. In this regime type, there is a more widespread view of housing as a financial investment that could be mobilized to compensate for austerity in the pension provision (Doling and Elsinga 2013, p. 142). Nevertheless, also in the United Kingdom, several barriers to releasing housing equity remain, such as mistrust of financial institutions (in case of using an ERS), the sense of security provided by outright home ownership and unwillingness to spend assets that were built up by hard work (Jones et al. 2012).

In the social-democratic countries (Finland and the Netherlands ${ }^{2}$ in DEMHOW), the pension provision system is reliable and relatively generous. As a result of this, there is less need to release housing equity in order to compensate for deficits in the welfare state and housing equity release plays a less important role (Doling and Elsinga 2013).

Other international comparative studies Based on an international comparative analysis of 50 micro-economic surveys from 15 OECD countries and adjusted for cohort effects, Chiuri and Japelli (2010) observed that countries with less developed mortgage markets and a limited or non-existent ERS market show a larger decrease in home ownership rates in old age than countries with a more developed mortgage and ERS market. They

\footnotetext{
${ }^{1}$ In Germany, where the home ownership rate is much lower than in the other DEMHOW countries not only inheriting owner-occupied dwellings, but also ownership of rental dwellings is often part of the family strategy.

2 Although the Dutch welfare state regime has both social-democratic and corporatist characteristics, the attitudes towards housing equity seem to be rather similar to those in the social-democratic welfare regime (Doling and Elsinga 2013, p. 143).
} 
hypothesize that the availability of options to withdraw housing equity without the need to sell the property (i.e. using an ERS) may lead to less moves to the rental sector in old age. Thus, strategies to release housing equity that don't require moving may serve as communicating vessels with housing equity release strategies that do require such moves.

Delfani et al. (2014) have investigated how the institutional characteristics in the housing and pension domain affect the possibilities to release housing equity in an asset-based welfare strategy. Based on theoretical arguments, the authors assume that a real trade-off between housing equity and pension provision is only possible if both housing and pensions are commodified and mediated by market forces. In such a situation, home ownership and private pensions can function as substitutes since both are voluntary and exposed to market risks. After making an international comparative analysis of both housing (size of mortgage market, rent regulation regime) and pension indicators (expenditure for mandatory pension provision, poverty among pensioners), Delfani et al. (2014) conclude that such a 'double commodification' only exists in the liberal welfare state regimes.

Haffner et al. (2015) looked at the relation between institutional settings and the development of the ERS market. These authors selected six countries with clearly different mortgage and housing finance markets and mapped the availability of ERS for each of these countries. They concluded that Australia, the UK, the USA and the Netherlands have a comparatively well-developed ERS market, whereas Germany and Finland clearly lag behind in this respect. Among other things, the authors explain this divergence by referring to differences in the size and liberalization of mortgage markets and to differences in house price appreciation. They furthermore conclude that specific institutional features, such as the tax regime and the type of mortgages available (fixed or flexible interest rates), have a clear influence on the particular size and shape that the ERS markets in Australia, the UK, the USA and the Netherlands take.

\subsection{Single-country studies}

There are also various single-country studies that have assessed the consumer's interest in releasing housing equity or using an ERS. These studies seem to suggest that the interest in this strategy is growing. For example, in the Netherlands, a 2012 survey on the demand for ERS (Dillingh et al. 2017) showed that $27 \%$ of the home owners aged above 45 would be interested in using a reverse mortgage. Particularly, households with low pension entitlements (for example independent professionals), households who are asset-rich and incomepoor and households who are expecting major expenses turned out to be interested. Also, in an Italian study (Fornero et al. 2015), those people who worry about their post-retirement standard of living were the ones that expressed most interest in ERS (although in this country, the 'average' interest in ERS still turned out to be rather low).

In the United Kingdom, generally considered as the most mature ERS market in Europe, the demand for equity release products has been steadily growing in size since the Global Financial Crisis. Nevertheless, the ERS market in this country is still rather small compared to the market of standard mortgages, covering about half a per cent of the total mortgage market (Fox O'Mahony and Overton 2015). Also, referring to the UK, French et al. (2018) observe that there is a clear connection between house price levels and the interest in releasing housing equity. Regions with high house values tend to have higher levels of 
housing equity withdrawal, as households in these areas can release a greater amount of equity.

It is important to note that the interest in housing equity release correlates with age and age groups (cohorts). Based on qualitative research in the United Kingdom and Germany, Jones et al. (2012) conclude that the emotional value of a house increases with age, while the willingness to consider housing equity as an asset decreases. In an Australian study (Olsberg and Winters 2005) showed that younger generations, being less risk-averse and giving less importance to bequest, are more prone to release housing equity in old age than older generations. In the research of Dillingh et al. (2017), respondents between 45 and 65 showed more interest in releasing housing equity than respondents above 65 . The authors speculate that this is due to the fact that people below 65 years of age anticipate a substantial drop in income after retirement.

Whereas interest in releasing housing equity seems to be on the rise in the Netherlands and the United Kingdom, there are also several countries in which institutional and cultural context remains quite unfavourable for releasing housing equity, particularly by means of ERS. Mikeszová and Lux (2020) have shown that in the Czech Republic, even the younger generations (ages 40 to 55), do not regard home ownership property as an asset that could be used to increase their quality of life in old age. This is due to a variety of factors such as the ontological security that outright home ownership provides, the bequest motive, reluctance to take on debt and the negative image of suppliers of ERS.

\section{Research methods}

The research findings that are discussed in this paper are the result of focus group research (see Stewart and Shamdasani 1990, for more details on this research method) in which housing equity release-related topics were discussed with a group of predominantly older home owners. Three focus groups took place in each of the six countries. The first two focus groups involved a general exploration of attitudes towards home ownership, the use of housing equity and bequest, whereas the third focus group aimed to reveal the participant's appreciation of a selection of specific equity release products. This paper focuses on the results of the first two focus groups. Depending on the country, the focus groups were carried out in the last half of 2016 or the first half of 2017. The focus group participants were recruited via consumers organisations and through the networks of the participating universities. In order to ensure a high level of comparability, the same semi-structured discussion guide was used in all participating countries.

Composition of the focus groups Table 2 gives an overview of the participants of the 12 focus groups. In most countries, it was possible to form groups with about 6 to 9 participants, which is the advised group size (Stewart and Shamdasani 1990). In Hungary, one focus was somewhat smaller than that, whereas in Italy group sizes were bigger. In Italy and Ireland, the researchers decided to organise focus groups in two different locations, in order to examine the influence of regional housing market conditions.

The large majority of the focus group participants were home owners with an age above 55 , which implies that they were generally old enough to have retired, or at least have thought about retirement. In most countries, all or almost all the focus group participants 
Table 2 Number of participants, location, age distribution and mortgage characteristics of the 12 focus groups. Source: Al-Umaray (2018)

\begin{tabular}{lllll}
\hline & $\begin{array}{l}\text { Number of } \\
\text { participants }\end{array}$ & Location & Age distribution (min-max) & $\begin{array}{l}\text { Participants } \\
\text { without mort- } \\
\text { gage }\end{array}$ \\
\hline Hungary 1 & 9 & Budapest & $61-75$ & All \\
Hungary 2 & 3 & Budapest & 74 & All \\
Italy 1 & 15 & Parma & $56-83$ & Large majority \\
Italy 2 & 9 & Rome & $57-77$ & Large majority \\
Ireland 1 & 10 & Waterford & Predominantly $>55$ & Large majority \\
Ireland 2 & 7 & Dublin & Predominantly $>55$ & Large majority \\
The United Kingdom 1 & 7 & Belfast & $63-75$ & Large majority \\
The United Kingdom 2 & 6 & Belfast & $51-90$ & Large majority \\
Germany 1 & 8 & Hamburg & $65-82$ & Large majority \\
Germany 2 & 9 & Hamburg & $51-69$ & Large majority \\
The Netherlands 1 & 8 & Delft & Mainly 55-75 & Minority \\
The Netherlands 2 & 8 & Delft & Mainly 55-75 & Minority \\
\hline
\end{tabular}

had repaid their mortgages entirely, which implies that they have a considerable amount of housing equity accumulated. The household income was not used as a criterion for the selection of focus group participants and the focus groups were composed of people with a variety of income levels.

Data analysis All focus groups discussions were recorded with an audio device. Based on the audio recordings, full transcripts of the discussions were made in the national language. Furthermore, a 10 to 15 page English summary with the main findings was produced for each focus group. These summaries, which followed the structure of the semi-structured discussion guide and also included salient quotations, constitute the empirical basis for the current paper. The focus group summaries have been analysed by means of a structured content analysis.

\section{Empirical results}

This Section discusses the main results of the focus group discussions. The following topics will be dealt with:

- Attitudes towards the different housing equity release strategies (Sects. 5.1 to 5.6)

- Attitudes towards the bequest motive (Sect. 5.7)

\subsection{Measuring attitudes towards different forms of housing equity release}

In a so-called vignette (Fig. 1), the focus group participants were presented with the hypothetical situation of a pensioner's household that had financial troubles. Subsequently, they were asked to give advice to the household in the vignette by ranking the presented housing equity release options from most preferred to least preferred. Although the older home 


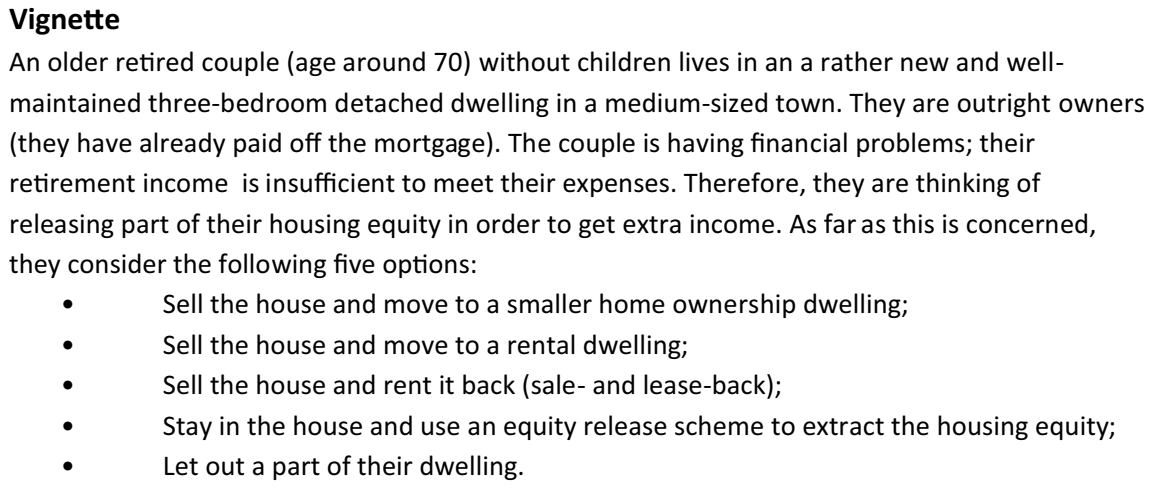

An older retired couple (age around 70) without children lives in an a rather new and wellmaintained three-bedroom detached dwelling in a medium-sized town. They are outright owners (they have already paid off the mortgage). The couple is having financial problems; their retirement income is insufficient to meet their expenses. Therefore, they are thinking of releasing part of their housing equity in order to get extra income. As far as this is concerned, they consider the following five options:

- $\quad$ Sell the house and move to a smaller home ownership dwelling;

- $\quad$ Sell the house and move to a rental dwelling;

- $\quad$ Sell the house and rent it back (sale- and lease-back);

- Stay in the house and use an equity release scheme to extract the housing equity;

- Let out a part of their dwelling.

Fig. 1 The vignette that was used in the focus group discussions Source:Al-Umuray, 2018

owners were asked to advise the people in the vignette, they generally also used their own personal situation and context as a frame of reference.

The average results of this ranking exercise are presented in Table 3. In the next subsections, the focus group participants' motivations for providing a particular ranking are discussed in more detail. Doing so, we first outline the general trends within our research findings after which we describe the most salient differences between countries (if applicable). We amply use salient quotations in order to illustrate our research findings and come up with a narrative.

\subsection{Selling and moving to a smaller owner-occupancy dwelling (downsizing)}

General findings In all countries expect Italy, downsizing was the most preferred housing equity release option. This option is relatively easy to understand and to perform, and it allows households to continue to be home owners. However, it does require that people leave their current house. For some people, this can be problematic, as many older households have an emotional attachment to their dwelling and they prefer to stay in it as long as possible (ageing in place). During the focus group discussions, we clearly observed that downsizing is not necessarily related to a deliberate housing equity release strategy. In practice, housing equity release considerations are often mixed with considerations concerning the appropriateness of the dwelling for ageing in place. Whatever the case, older home owners who downsize often choose to move within the same community.

No, I think people might want more to stay in the community basically, you know, the familiars or surroundings. If God forbid, my wife dies, I will be on my own in a four bedroom house. What do I want a four bedroom house for? (Ireland).

I am enjoying my house less than before because my grandchildren are now too old to play in the garden. The house is big and requires a lot of maintenance. I am not sure if it is a good idea to keep on living there. The question is what strategy 


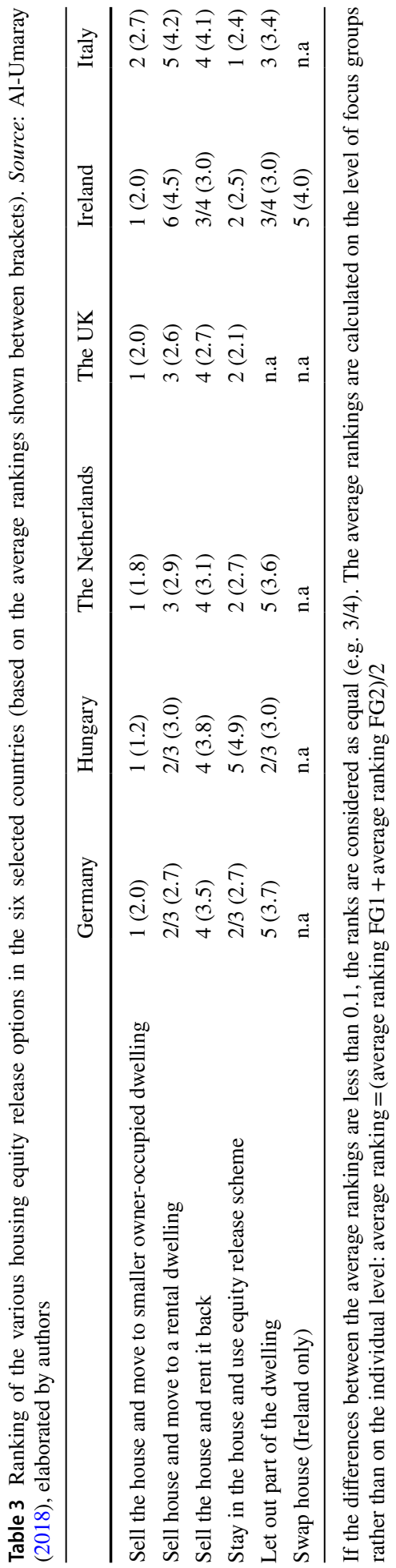


is best for us, not so much in financial terms but more in terms of our physical and mental health (the Netherlands).

Selling and buying something smaller that is age-adequate in a good option, especially if you can also have an extra room for a care giver to be able to stay there as it is cheaper than paying for an old-people's home (Germany).

Although downsizing seems a straightforward option, the focus group discussions made clear that the potential for realizing this strategy is highly dependent on the local housing market situation. For example, selling a house might be difficult in areas with a shrinking population, whereas finding a suitable and affordable smaller dwelling might be complicated in areas with a tight housing market, such as bigger cities.

International and intra-national variations In Italy, the interest in 'downsizing' was comparatively less strong, which may reflect the strong cultural value of the family house in this country. However, a significant intra-country difference was visible in Italy as well. While the Rome focus group saw some potential in selling up and buying a smaller property, most of the participants in Parma mentioned a strong emotional attachment to their current dwelling:

For me moving to a different place would mean shortening my life (Parma, Italy).

\subsection{Selling and moving to a rental dwelling}

General pattern The option to sell the house and move to a rental dwelling found reasonable support in Germany, Hungary, the Netherlands and the United Kingdom. Apart from the release of housing equity, the main advantage of this option is the lack of responsibility for maintenance.

If you are 85, you don't have the energy anymore to contract people that will maintain your dwelling. It is then better to rent (The Netherlands).

I consider renting as less exhausting than owning a house (Germany).

The downside of this option is the high housing costs, as well as insecurity about future rental payments.

For a similar house you will pay more so your housing costs will increase (the Netherlands).

Utility costs and overheads are terribly high together (...) these are not even your own utility costs, you pay for the heating in the staircase, for the light... (Hungary).

International and intra-national differences In Italy, selling up and renting another property received the lowest rank. This seems to be related to home ownership as a cultural ideal. In Rome, the focus group participants also referred to the high rent levels in this city. In Ireland, this option was appreciated differently within the country. Whereas in Waterford, selling up and renting attracted some support, in Dublin the rental options were ranked as inferior. The Dublin participants explained that rental prices in the capital city are very high, which makes renting an unattractive option. 


\subsection{Selling the dwelling and renting it back (sale-and-lease back)}

General pattern The idea of selling the dwelling and leasing it back is not very popular in the selected countries, with limited international and intra-national differences in the rankings that were given. The focus group participants argued that sale-and-leaseback constructions are financially unattractive and leave the former home owners at the mercy of the future landlords, thus leading to insecurity. In order to limit this risk, the importance of carefully checking the conditions (selling price, future rent, tenure security, responsibility for maintenance) of sale-and-lease back arrangements before engaging into them was stressed. In Germany, some older focus group participants argued that they strongly identified with their status as property owners, and thus considered it strange to rent back the dwelling that they previously owned.

Selling the house and renting it back, I suppose there is a danger in that if you are going to make a budget, you know how much rent you can pay back, but the rent can go up. So, you have to think if you can be able to afford that in a longer term (the UK).

It is very commercial. You become dependent on the landlord and you lose your say over the dwelling (the Netherlands).

Someone may give up his identity or his principles, but in any case he has to keep his independence and his financial security (Hungary).

\subsection{Using an Equity Release Scheme (ERS)}

General pattern While selling and buying a new property was overall the most preferred housing equity release option, using an ERS was second most advised option in all countries except Hungary. In Italy, this option even came in the first place. Again, this seems to be related to the important role for the Italian family and the strong emotional ties to the family house (see also Sect. 5.2), which result in a clear aversion against having to move in old age.

I think it is important to live in the same house also from a practical point of view because you get used to that space and you know how to move around in that place. This is very important, especially for those elderly that are not autonomous, living in the same house means that they would have some reference points to move around (Italy).

Even though the interest in ERS was considerable, hardly anyone had real experience with, or specific knowledge about, these schemes. Indeed, the focus group participants expressed a clear need for more objective information on this topic so that they would be better able to assess the specifics, as well as the pros and cons, of ERS. Furthermore, the focus group discussions made clear that ERS not only lack transparent product information, but also 'suffer' from a lack of trust in financial institutions and regulators. Many people have not yet forgotten about the negative press that many financial institutions received in the aftermath of the Global Financial Crisis. 
I don't trust it. If you think about what happened in recent years. With mortgages and everything.... I would say no... (the Netherlands).

The PVI (prestito vitalizio ipotecario, government supported ERS) is a good idea but there is no future for it, at least with these politicians (Italy).

International variations In Hungary, staying in the dwelling and using an ERS was the least preferred of all five available housing equity release options. Hungarian older home owners showed a very strong distrust towards banks and mortgages, even more so than in the other selected countries. This might be related to the fact that in Hungary, mortgage provision in foreign currencies has resulted in much trouble after the global financial crisis (Csizmady et al. 2019) and led to the annulation of the available ERS products.

You cannot trust even in banks $100 \%$, because even if they are here now, tomorrow they disappear (Hungary).

\subsection{Let out part of the dwelling}

General pattern: international and intra-national variations The option 'let out part of the dwelling' was the equity release strategy that showed most differences in appreciation between countries. In the Netherlands and Germany, it was ranked as the least preferred option. The main reason was that participants would not feel good when having other people in their house:

Because you are in financial trouble you let other people in your house. I do not think this is a good motivation for subletting part of your dwelling (the Netherlands).

As a 70 year old, you should not let strangers in to your home (Germany).

In Hungary, letting out part of the dwelling was a relatively popular option. This appears to be related to the strong Hungarian aversion against financial products and financial institutions. In such a context, subletting is relatively attractive since it does not depend on financial institutions and it allows older home owners to extract housing equity while staying in their dwelling.

In Ireland and Italy, there were remarkable differences between cities. In Dublin, renting out an extra room actually received the highest rank. Some participants had first-hand positive experiences with renting out rooms to University students. In Waterford on the contrary, renting out a room (or part of the dwelling) was ranked as the least favoured option, probably because rent levels in this city are considerably are lower than in Dublin. In Italy, a similar division was visible between Rome (high rent levels, favourable perception of subletting) and Parma (lower rent levels, less favourable perception of subletting).

\subsection{Attitudes towards bequest}

According to previous studies (e.g. Toussaint 2011), a factor that potentially reduces the willingness to release housing equity is the traditional bequest motive (leaving a heritage to the children after one passes away). It is argued that older home owners are reluctant to extract housing equity because this would hamper the possibilities to transmit the family 
dwelling to their offspring. In our own research, this traditional view on bequest turned out to be prevalent in Hungary and, to a somewhat lesser extent, Italy.

I don't think inheritance is important. They inherit the dwelling (Hungary).

Leaving a bequest is leaving part of myself to my children, it is a way of staying alive after death (Italy).

In the other four countries, the traditional bequest motive seems to be less important. Many older home owners still desire to leave something to their children, but this is not their ultimate goal in life. Moreover, particularly in the Netherlands, several older home owners indicated that they prefer to help their children by means of inter-vivo transfers (advanced inheritance) rather than by a traditional inheritance.

My children need the money now, for studying, buying a house, raising children. I prefer to support them now rather than that they have to wait until I die. But of course, I want to keep some buffer so that they don't have to support me when I get older. I would not like that (the Netherlands).

Thus, rather than being a barrier for housing equity release, the bequest motive (but in a less traditional form) can actually be a reason for extracting housing equity. One Dutch participant has already put this into practice.

I have bought a new apartment that will be finished in 2018. The price of this new apartment is much lower than the value of my current house and with the difference I can help my children. They are just starting their housing career and I help them with financing their first home ownership dwelling (the Netherlands).

Finally, there is a group of older home owners for which the bequest motive, in whatever form, simply is less important. These people argue that they have already spent much money on rearing and educating their children. They feel that their offspring should be prepared to enter society and fend for themselves.

For me, when you are older, it is the time to look after yourself. You have already educated your children. It is time to concentrate on yourself (the UK).

I have no intention to pass on the asset as I will use the money myself if I can, my kids are doing well (Germany).

\section{Conclusion and discussion}

The goal of this paper was to assess the attitude of older home owners towards the different forms of housing equity release, as well as towards the bequest motive. This assessment was based on 12 focus group discussions (two per country) in six selected countries: the United Kingdom, Germany, the Netherlands, Ireland, Italy and Hungary. We feel that some interesting new trends emerged from our research. In the remainder of this Section, we describe and interpret these trends against the background of the contextual differences between countries (Sect. 2) and the literature review (Sect. 3). Doing so, we make a distinction between more general trends on the one hand, and trends that refer to international or intra-national differences on the other. Furthermore, we identify some salient questions for future research. 
When interpreting our conclusions, it is important to note that our research has had a qualitative character and does not allow for statistical generalization. The number of focus group participants has been fairly small and it is unclear to what extent these participants are really representative for the older home owners in the selected countries. Thus, the trends and observations that are discussed below should be seen as hypotheses rather than as absolute research findings. Follow-up quantitative research is needed to give them a more solid underpinning.

General trends First of all, we observe that overall, and some notable exceptions aside, the preferences for the various housing equity release strategies are fairly comparable between the selected countries. Based on the work of Chiuri and Japelli (2010), Delfani et al. (2014) and Haffner et al. (2015), one might have expected that the ERS option would be relatively popular in the market oriented liberal welfare state regimes (UK, Ireland), where the mortgage market is well developed and the housing market is relatively commodified. In a similar vein, the downsizing/moving to rental options was assumed to be relatively popular in the other welfare regime types, where housing markets are more de-commodified and/ or mortgage markets are less developed. However, we did not observe this expected pattern in our analysis. Limitations regarding sample size and sample composition may play a role here. Nevertheless, the observed deviation from the expected pattern might also be related to the fact that the vignette that was used in the focus group discussions mainly perceived the use of an ERS as a hypothetical housing equity release strategy. No reference was made to the actual availability of ERS in the countries under investigation. During the focus group discussions, it turned out that the focus group participants were generally not knowledgeable on this matter. In all countries, also in the UK and Ireland, most of the participating home owners stated that they had no experience with, or specific knowledge of, ERS. This raises the question to what extent a baseline consumer's interest in ERS is a structural feature of all European welfare state regimes (perhaps with the exception of the Eastern European regime type), and to what extent this interest is influenced by the actual size and development of the national ERS markets. Further research is needed to get a better insight into this issue.

Second, we did not find a clear correlation between the ranking of the various housing equity release options (Table 3 ) and the generosity of the mandatory pension system (see Table 1). This may be due to the fact that all five housing equity release strategies can be used for improving the retirement income. Furthermore, our research clearly shows that not all (desired) housing equity release takes place for the purpose of pension supplementation. Helping offspring to make a start on the housing market may also be an important motivation, just as renovation or maintenance of the dwelling. Ultimately, the decision to release housing equity, and how to do this, is influenced by both contextual (welfare state regime, pension system, fiscal aspects, culture, housing market situation) and individual (amount of money needed, housing situation, health, presence of children) factors. Ideally, researchers and policy makers in the field of housing equity release should take all these factors, as well as their mutual interdependence, into account.

Third, we observed that the older home owners in our focus group discussions attached less importance to the bequest motive than we would have expected on the basis of the findings of the DEMHOW project (Toussaint and Elsinga 2009; Toussaint 2011). In our qualitative research, quite a few older home owners stated that they have already provided a lot of support to their children, and that providing a traditional inheritance is of lesser 
importance. Moreover, the older home owners that were still eager to support their offspring often thought that providing inter-vivos transfers (advanced inheritance) is more fruitful than leaving behind a traditional inheritance. Particularly in the Netherlands, the provision of such inter-vivo transfers was mentioned as a good reason for releasing housing equity.

In our opinion, various factors may explain this potential shift in attitudes towards bequest. First of all, changes in the national pension and health care systems, which are becoming less generous and inclusive, may make home owners realize that they might need to use their housing equity for maintaining their own well-being in old age. Second, housing markets are becoming more and more unaffordable and inaccessible for young people (see also Wetzstein 2017), which likely explains the increasing interest in providing inter-vivos intergenerational transfers. Third, cohort effects (different attitudes towards bequest among different generations) may play a role, even though the time span between the DEMHOW research and the research discussed here is only about eight years. Further research is needed to scrutinize the impacts of these three factors, as well as international variations with regard to these impacts, in more detail.

International and intra-national differences The general trends discussed above are based on a cross-country generalization. It should be noted that not all countries in our analysis equally conform to this generalization. With regard to the appreciation of the various housing equity release strategies and the importance of the traditional bequest motive, particularly Italy and Hungary show some deviations from the general pattern.

In Italy, older home owners expressed a strong attachment to their current dwelling. In this Mediterranean welfare state, the (extended) family still occupies a key role in society, which is reflected in the importance of the traditional bequest motive. Home ownership is perceived as a cultural ideal and a family project (Doling and Elsinga 2013) and many older home owners find it important that the family dwelling remains in the family.

Very similar trends can be seen in Hungary as well. Moreover, older Hungarian home owners showed a remarkably strong aversion against mortgages and ERS schemes. Since Mikeszová and Lux ( 2020) also observed such an aversion in their study on housing equity release in the Czech Republic, we hypothesize that it can be seen as a typical feature of the Eastern European welfare state regime.

Finally, our research has shown that also within a country (intra-national), there may be variations in the appreciation of the different housing equity release strategies. Often, these variations are due to differences in housing market context (see also French et al. 2018). For example, in cities with a tight housing market (Dublin and Parma in our research), subletting is a relatively attractive housing equity release option, whereas moving to another rental dwelling might be complicated and expensive. In cities with a more relaxed housing market on the other hand (Waterford and Parma in our research), it is likely to be the other way round. Future comparative research on housing equity release should be sensitive towards such regional differences and take the local housing market context into account.

Acknowledgements The authors gratefully acknowledge financial support from the European Commission Grant VS/2015/0218. We also thank all the researchers and focus group participants that contributed to the research that was funded with this grant. Without their input, the present paper would not have been possible. 


\section{Compliance with ethical standards}

Conflict of interest The authors declare that they have no conflict of interests.

Ethical statement All focus group participants participated voluntary and remain completely anonymous in this paper.

Open Access This article is licensed under a Creative Commons Attribution 4.0 International License, which permits use, sharing, adaptation, distribution and reproduction in any medium or format, as long as you give appropriate credit to the original author(s) and the source, provide a link to the Creative Commons licence, and indicate if changes were made. The images or other third party material in this article are included in the article's Creative Commons licence, unless indicated otherwise in a credit line to the material. If material is not included in the article's Creative Commons licence and your intended use is not permitted by statutory regulation or exceeds the permitted use, you will need to obtain permission directly from the copyright holder. To view a copy of this licence, visit http://creativecommons.org/licenses/by/4.0/.

\section{References}

Al-Umaray, K. and 27 other authors (2018). Integrating residential property with private pensions in the $E U$. Final report. Hamburg: IFF.

Chiuri, M. C., \& Japelli, T. (2010). Do the elderly reduce housing equity? An international comparison. Population Economics, 23, 643-663.

Csizmady, A., Hegedüs, J., \& Vonnák, D. (2019). A housing regime unchanged: The rise and fall of foreign-currency loans in Hungary. Corvinus Journal of Sociology and Social Policy, 10(2), 3-34.

Dillingh, R., Prast, H., Rossi, M., \& Brancati, C. U. (2017). Who wants to have their home and eat it too? Interest in reverse mortgages in the Netherlands. Journal of Housing Economics, 38, 25-37.

Delfani, N., De Deken, J., \& Dewilde, C. (2014). Home-ownership and pensions: Negative correlation, but no trade-off. Housing Studies, 29(5), 657-676.

Doling, J., \& Elsinga, M. (2013). Demographic change and housing wealth: Homeowners, pensions and asset-based welfare in Europe. Dordrecht, Heidelberg, New York, Londen: Springer.

Doling, J., \& Ronald, R. (2010). Property-based welfare and European home owners: How would housing perform as a pension? Journal of Housing and the Built Environment, 25(2), 227-241.

Ebbinghaus, B. (2015). The privatization and marketization of pensions in Europe: A double transformation facing the crisis. European Policy Analysis, 1(1), 56-73.

Eckardt, M., Dötsch, J., \& Okruch, S. (eds.) (2018). Old-age provision and homeownership-fiscal incentives and other public policy options. Springer.

Elsinga, M. (2011). A qualitative comparative approach to the role of housing equity in the life cycle. International Journal of Housing Policy, 11(4), 357-374.

Elsinga, M., \& Hoekstra, J. (2015). The Janus Face of homeownership-based welfare. Critical Housing Analysis, 2(1), 32-41.

Fenger, H. J. M. (2007). Welfare regimes in Central and Eastern Europe: Incorporating post-communist countries in a welfare regime typology. Contemporary issues and ideas in social sciences, August 2007, pp. 1-30.

Fornero, E., Rossi, M. C., \& Brancati, M. C. U. (2015). Explaining why, right or wrong (Italian) households do not like reverse mortgages. Journal of Pension Economics and Finance, 15(2), 180-202.

Fox O'Mahony, L., \& Overton, L. (2015a). The future of the UK equity release market: Consumer insights and stakeholder perspectives. University of Essex/The Leverhulme Trust.

French, D., McKillop, D., \& Sharma, T. (2018). What determines UK housing equity withdrawal in later life? Regional Science and Urban Economics, 73, 143-154.

Haffner, M., Hoekstra, J., Oxley, M., \& van der Heijden, H. (2009). Bridging the gap between social and market rental housing in six European countries? Amsterdam: IOS Press.

Haffner, M. E. A., Ong, R., \& Wood, G. A. (2015). Mortgage equity withdrawal and institutional settings: An exploratory analysis of six countries. International Journal of Housing Policy, 15(3), 235-259.

Hoekstra, J. (2010). Divergence in European housing and welfare systems. Amsterdam: IOS Press. 
Jefferson, T., Austen, S., Ong, R., Haffner, M., \& Wood, G. (2017). Housing equity withdrawal: Perceptions of obstacles among older Australian home owners and associated service providers. International Journal of Social Policy, 46(3), 632-642.

Jones, A., Geilenkeuser, T., Helbrecht, I., \& Quilgars, D. (2012). Demographic change and retirement planning: Comparing households' views in the role of housing equity in Germany and the UK. International Journal of Housing Policy, 12(1), 27-45.

Lennartz, C., \& Ronald, R. (2017). Asset-based welfare and social investment: Competing, compatible or complementary social policy strategies for the new welfare state? Housing, Theory and Society, 34(2), 201-220.

Malpass, P. (2008). Housing and the new welfare state: Wobbly pillar or cornerstone? Housing Studies, 23(1), 1-19.

Mikeszová, M., \& Lux, M. (2020). Dilemmas of housing-asset based welfare in the post-socialist context: The case of the Czech Republic. International Journal of Housing Policy, 20(3), 367-389.

Naumanen, P., Perista, P., \& Ruonavaara, H. (2012). Homes as old age security? Households' perceptions' of housing and elderly care in Finland and Portugal. International Journal of Housing Policy, 12(1), 47-68.

Olsberg, D., \& Winters, M. (2005). Ageing in place: Intergenerational and intrafamilial housing transfers and shifts in later life, Final Report No. 88, Melbourne: Australian Housing and Urban Research Institute.

Prabhakar, R. (2018). A house divided: Asset-based welfare and housing asset-based welfare. International Journal of Housing Policy, 19(2), 213-231.

Reifner, U., Clerc-Renaud, S., Perez-Camillo, E., Tiffe, A., \& Knobloch, M. (2009). Study on equity release schemes in the EU. Hamburg: IFF.

Ronald, R. (2008). The ideology of home ownership. Homeowner Societies and the Role of Housing: Palgrave Macmillan.

Sherraden, M. (2003). Assets and the social investment state. In W. Paxton (Ed.), Equal shares: Building a progressive and coherent asset based welfare strategy (pp. 28-41). London: IPPR.

Stewart, D. W., \& Shamdasani, P. N. (1990). Focus groups. Theory and practice. Applied Social Research Methods Series Volume 20, Newbury Park/London/New Delhi: Sage Publications.

Toussaint, J. (2011). Housing wealth in retirement strategies. Towards understanding and new hypotheses. Amsterdam: IOS Press, .

Toussaint, J., \& Elsinga, M. (2009). Exploring 'housing asset based welfare'. Can the UK be held up as an example for Europe? Housing Studies, 24(5), 669-692.

Wetzstein, S. (2017). The global urban housing affordability crisis. Urban Studies, 54(14), 3159-3177. https ://doi.org/10.1177/0042098017711649.

Publisher's Note Springer Nature remains neutral with regard to jurisdictional claims in published maps and institutional affiliations. 